\title{
ACTR3B Gene
}

National Cancer Institute

\section{Source}

National Cancer Institute. ACTR3B Gene. NCI Thesaurus. Code C152040.

This gene may play a role in actin binding and org anization of the cytoskeleton. 